\title{
The Effects of Tangible and Intangible Salience on Conflict
}

Author: Emily Barrett

Faculty Mentor: Paul Hensel, Department of Political Science, College of Arts and Sciences, University of North Texas

Department and College Affiliation: Department of Political Science, College of Liberal Arts and Sciences, University of Illinois at Urbana-Champaign 


\section{Bio:}

Emily Barrett is a student at the University of Illinois at Urbana-Champaign majoring in Political Science. She is currently a senior and an active member of Conversational Partners where students tutor international students in conversational English. Beyond academic activities, Emily's interests revolve around film and creative writing. Upon graduation Emily intends to enter a master's program in political science. 


\begin{abstract}
:
This research studies the interaction effect of tangible and intangible salience on the management of contentious issues between countries. I am theorizing that, due to the great impact high tangibility and intangibility have on a conflict individually, having these two dimensions within the same conflict would cause them to have an interaction effect on one another, enhancing and/or affecting each other's role within the contentious issue. It is also hypothesized that when a contentious issue occurs with both high tangibility and intangibility, the likelihood of armed conflicts or peaceful settlements would increase. My finding is that when these two dimensions are within the same contentious issue, they do increase the probability of armed conflict but do not impact the result of the peaceful settlement.
\end{abstract}




\section{Introduction}

Territory has been researched and frequently cited as a primary source of contention, therefore it is important to examine the role territory has in conflicts and the underlying factors that make territory contentious. Past research has examined geography, contiguity, levels of salience, state rivalries, and other factors in an effort to understand what causes conflict and peace when territory is involved. All these factors play a role when it comes to contention over territory, but greater understanding is needed on the levels of tangible and intangible salience and their effect on one another. These dimensions are important in causing not only disputes, but also settlements between states. As previous studies have argued, "different types of issues vary along two general dimensions of salience: the tangible importance of an issue, such as economic or strategic value, and the intangible importance of an issue, such as prestige or identity value" (Hensel et al. 2008). These underlying issues of territory have a great effect on the outcome of the conflict.

Past research has looked into how the levels of salience of these dimensions individually affect the outcome of the conflict (Hensel \& Mitchell 2005), but previous studies have not investigated how these dimensions interact with one another and how they affect the conflict's outcome. The lack of research pertaining to this question leaves several unanswered questions about territory and the underlying factors that cause conflict and peace, such as:

- What is the interactive effect of these two factors upon one another and how does that interaction affect the outcome of the issue?

- Does the presence of one variable (e.g., intangible issues) enhance/affect the other (tangible issue) so that the sum is greater than just having two present at the same time? 
- Does the role of intangible issues increase tangible claims? Could intangible issues between two parties increase discord over tangible stakes and eventually infuse them with more tangible qualities?

These questions are not answered by previous research and all need to be further explored in order to understand how and why territory is contentious.

I argue that a contentious issue with high levels of both intangible and tangible salience is more likely to produce armed conflicts or peaceful agreements than issues lacking one or both of these dimensions. I develop this argument by reviewing the literature on territory and find that the interaction concept has not been researched and incorporated into territory literature. I will expand upon the relationship between the levels of tangible and intangible salience and how the different levels of salience affect the outcomes of armed conflicts and peaceful settlements for a contentious issue. In the methods section I discuss my research design and present the results of my analyses. I find strong support for my argument that different levels of salience have an effect on one another and on the outcome of the issue.

\section{Literature Review}

Scholars have identified several factors or reasons why war and conflict occur in the world. The leading factor of contention within conflicts is territory. Territory is not a sufficient condition of war, but it does dramatically increase the chance of war and conflict (Vasquez and Henehan 2001). In order to explain why territory plays such a significant role in causing contention, conflicts and escalation to wars, many scholars have analyzed MID data of the Correlates of War project, data on territorial claims and the ICOW (Issue Correlates of War) issue data. Previous research and studies of these data sets have furthered understanding territory and its role in contentious issues. 


\section{Militarized Interstate Dispute Data of the Correlates of War Project}

The Correlates of War project is the most basic source of data on territory (Vasquez 2009). This data set is broken down by the type of the actor-revisionist or non-revisionist. Actors classified as revisionist are further coded into four categories: territory, policy, regime, and other (Jones, Bremer, and Singer, 1996:178). The only recorded data come from demands that are made with threats or use of militarized force. This data set reveals the relationships between states, decisions and actors, allowing further explanation and information pertaining to territory.

The MID data set provides analyses on territory, states, wars, and relationships that develop over time. Paul R. Hensel (1996) empirically analyzes the effects territory has on conflicts, demonstrating that territory has a strong influence on conflict behavior and increases the chances for conflicts to escalate to full-scale interstate war. Additionally, Paul Senese (1996) investigates the escalation to war puzzle by examining how MIDs escalate and increase the gravity of an issue once the primary threshold of a conflict breaks (1996). Senese's research reveals that the role of contiguity and territory positively influences the likelihood of MIDs, but does not affect hostility escalation. Territory's influence upon the escalation to war, war and conflicts shows that territory plays an important role in both past and contemporary issues.

John Vasquez and Marie T. Henehan (2001) examine the relationship between territory and war through the MID data set. Their research shows that conflicts over territory account for the majority of wars in comparison to policies or regime factors (Vasquez and Henehan 2001). Additionally, they found that regime disputes are also prone to war and that they have a different behavioral profile than other disputes, and therefore should not be combined with other disputes in a general non-territorial category (Vasquez and Henehan 2001). However, Sarah McLaughlin 
Mitchell and Brandon C. Prins (1999) conclude that a large portion of MIDs involved factors other than territory like fisheries, maritime boundaries, and resources of the sea. They further defined the sources of conflict and the role territory plays in them.

The role of democracies has also been examined through the MID data set. Steve Miller and Doug Gibler (2009) reexamine interstate dispute behavior in democratic peace theory and the relationship between that concept and territory. They found through investigating the MID Correlates of War Data that democratic states resolve most of their threatening issues like territory before becoming a democratic state, so when they are a considered a democratic state they are less likely to be involved in disputes. Overall, these studies reveal the intricate and vital aspects that territory plays within conflicts, states, decisions, and democracies.

\section{Data on Territorial Claims}

Paul Huth (1996) has collected data mainly on territorial claims, which further explores the relationship between territory and contentious issues. This data was gathered for the period 1950 to 1990 and now has been extended back to 1919 (Huth and Allee, 2002). This data set breaks down territorial disagreements between states and codes them as strategic, economic, or ethnic questions, and it is helpful when examining the predispositions of different types of territorial issues (Vasquez 2009). Ultimately, the Huth data further explains what makes territorial issues more conflict prone.

Vasquez and Senese (2003) delve into the relationship between disputes and the probability that war will break out. This approach was previously criticized for underestimating the possible sampling bias found in the militarized interstate dispute (MID) data, so the researchers developed a new unified territorial explanation for why certain factors influence the rise of militarized disputes (Vasquez \& Senese 2003). They contend that territorial claims do 
increase the probability of militarized disputes occurring and territorial MIDs increase the probability of war. Ultimately, their new territorial explanation shows no sampling bias with regard to territory in MID data. This research provides greater information on the role of territory and the prospect of war breaking out. Again it shows that their relationship is both complex and very contentious.

\section{ICOW Data}

The ICOW data set further examines the relationship between contentious issues and territory. The ICOW data and the Huth data set are similar in that they both include disagreements that do not choose to the use of force or threats and are broader in both types of issues and their temporal domain (Vasqeuz 2009: Ch 10). Hensel's (2001:90-94) data set starts with territorial disagreements, which includes Huth's data, and goes back to 1816 in order to be compatible with the Correlates of war data.

Through this data set many scholars investigate the role of territory and its underlying dimensions. Paul R. Hensel and Sarah McLaughlin Mitchell (2005) contend there is a distinguishable difference between tangible and intangible issues and their effect on a given situation. Their research shows territorial claims with high intangible salience are significantly more likely to experience a greater number of militarized disputes and peaceful agreements, while tangible salience has a low impact on low level disputes and produce fewer agreements (Hensel \& Mitchell 2005). Additionally, in other research, Paul R. Hensel, Sarah McLaughlin Mitchell, Thomas E. Sowers II, and Clayton L. Thyne (2008) expound on this concept with an issue-based approach, revealing that states are more likely to have both militarized and peaceful methods when an issue with high salience is at stake. They find that the type and level of salience varies and it is important to distinguish the difference between them because the 
techniques to resolve it will be different. Paul R. Hensel (1999) studies the origins of enduring, militarized, interstate rivalry from an evolutionary perspective, which reveals that an evolutionary approach to studying rivalries and legacies of past events is important. Taking this approach allows more general understanding of rivalry, conflict, and world politics. These studies offer a broader understanding of the concept of territory and its effect on contentious issues, states, wars, and the escalation to war, but do not delve deeply into the factors that cause territory to be a contentious issue. Hensel, Mitchell, Sowers, and Thyne delve into this area of research by investigating the role tangible and intangible salience has upon a given situation but do not compare how different levels of tangible and intangible salience affect an issue. Overall, these studies provide information on how territory is the key to understanding war and peace. They expand upon the knowledge that territory issues are contentious by investigating how and why they are contentious.

\section{Theory}

Territory plays a significant role in current and past conflicts. It has been cited as the primary source of contention between states and we know that most wars arise from territorial disputes. Previous research by Hensel (1996) finds that when states are faced with territorial MIDs, they are much more likely to respond in a militarized fashion than when they are faced with non-territorial disputes. Territorial MIDs are also more prone to fatalities than other conflicts, which shows that the state and its people are willing to sacrifice their lives over these issues (Senese 1996). Of all the contentious issues states disagree on, territory is arguably the most salient and vital to states, and very difficult to settle peacefully (Vasquez 2009).

There are numerous factors which contribute to the outcomes of conflict but in order to further understand territory's role within contentious issues it is important to know how its 
underlying dimensions affect outcomes like armed conflict and peaceful agreement for an issue. Armed conflicts are operationally defined as militarized disputes, fatal militarized disputes and wars. A peaceful agreement is a conflict ending by either peaceful or violent means. Even though these terms are contradictory the fact that there was agreement made between the two states qualifies as a peaceful settlement. It is important to investigate the relationships between tangibility and intangibility and these outcomes of conflict because it will broaden the understanding of the concept of territory and how it is contentious.

Contentious issues can be viewed as having intangible and tangible dimensions, which affects the way that the issues are managed. These dimensions provide different resources, symbolic concepts, and protective terrain. To understand how and what makes territory contentious one needs to know what these dimensions are and what they mean to the people and the state. The intangible importance of an issue can include such values as prestige or identity (Hensel et al. 2008). Holy lands, ethnic conflict, religion and racial supremacy issues also fall under the concept of intangible dimensions. They give additional meaning and value to the land and create symbolic and cultural concerns, such as ethnic conflict, racial supremacy, cultural identity, and holy lands -- among many others -- contribute to the intangible salience of a territory (Vasquez 2000). It seems reasonable to expect that intangible salience has a greater impact than tangible salience on critical militarized disputes or interstate wars and is more likely to produce more peaceful agreements. The reasoning for the prediction that it will produce more peaceful agreements is that it has been argued that territory has a "psychological importance for nations that is quite out of proportion to its intrinsic, strategic or economic value" (Luard 1970). Thus, intangible dimensions are important to the actors involved, making it important to find a peaceful settlement because it is in the best interests of the actors. 
Another aspect of contentious issues is the tangible dimension. The tangible importance of an issue typically refers to its economic or strategic value (Hensel, Mitchell, Sowers \& Thyne 2008:138). This can include such elements as mountain ranges, strategic terrain, rivers, and natural resources. These resources provide security by providing absence of threats or protection from threats, survival for the state through the provision of food, water, and shelter, and wealth due to the goods or money that the land provides for the state (Hensel et al., 2008). These aspects of land are important for the sustainability of the state. Previous studies reveal tangible issues are not as likely to see their claims militarized as intangible issues (Hensel and Mitchell 2005).

However, this does not mean that tangible factors are not important to the state. Tangible issues have caused many disputes because of valuable resources or commodities, such as access to the sea or commerce routes. Additionally, these factors contribute to a state's perceived power and security by the resources and access they provide. They provide aid in national defense through their terrain. Fearon (1995) contends that territory with such tactical tangible attributes can be an important factor in war even for rivals who would otherwise favor a negotiated settlement, because the transfer of tactical terrain can change the two sides' relative bargaining positions. Control over the transferred terrain, therefore, can amplify the gaining side's ability to successfully attack or defend itself in the future, which causes both sides to be unwilling to allow a peaceful transfer of territory (Hensel 2000).

There are four possible combinations of the levels of tangible and intangible salience for a contentious issue. The impact of each dimension may depend at least partly on the value of the other dimension. That is, the interaction between the levels of tangible and intangible salience in a given issue may help to explain the probability of armed conflicts and peaceful agreements 
over an issue, providing greater insight into conflict and agreements. From this, the following hypotheses are generated.

Hypothesis 1: Contentious issues with high levels of both tangible and intangible salience are more likely to produce armed conflicts than issues with low levels on one or both salience dimensions, particularly for more severe forms of conflict.

Hypothesis 2: Contentious issues with high levels of both tangible and intangible salience are more likely to produce peaceful agreements than issues with low levels of one or both salience dimensions.

These contentious issues put both concrete and symbolic factors at stake for a country, making the issue more important to fight over, therefore, resulting in more peaceful agreements and armed conflicts. Refer to Table 1. These types of issues also allow for intangible issues to infuse symbolic concepts and cultural identity into concrete tangible stakes. This can arise due to repeated disputes, wars, or historical events over the tangible stakes, which infuse intangible characteristics into them. This concept has been incorporated into the work of Mansbach and Vasquez (2009), who claim that a stake within issues that change from concrete to symbolic to transcendent increases the probability of conflict and war dramatically. The ICOW data, however, measures the importance of an issue by accounting for the interactions that have occurred over a claim. Through past studies, Hensel, Mitchell, Sowers \& Thyne "expect that past efforts to manage a given issue will have an important influence on subsequent efforts to manage the same issue, with both militarized conflict and peaceful settlement attempts being more common for issues with recent histories of armed conflict and/or failed peaceful efforts" (2008). Even though these types of situations do not take into account the level of salience of an issue, only how many times there was an interaction that occurred over them, these concepts could be 
connected through their effect on the outcomes of the issues. They demonstrate that the number of failed attempts at settling an issue affects the importance associated with the conflict, which also affects the level of salience associated with the conflict.

\section{Research Design}

I test my argument by analyzing the territorial claims data from the Issue Correlates of War (ICOW) Project, which currently covers claims of territory in the Americas and Western Europe from 1816-2001 and considers a territorial claim to exist when "official representatives of at least one state make explicit statements claiming sovereignty over a piece of territory that is claimed or administered by another state" (Hensel, 2001, p. 90). An ICOW territorial claim exists only when a government official representative makes a clear claim of sovereignty over a specific piece of territory, which excludes any private organizations or individuals that make statements about territory claims. Additionally, the salience of an issue is considered the "degree of importance attached to that issue by the actors involved" (Diehl, 1992). In relation to territorial issues, salience is the importance level that is connected to the current territorial issue. The ICOW data set salience measure has two important advantages for my research: first, it allows for comparison both within and across issues types; and second, both militarized and peaceful attempts to manage or settle each issue are identified. This allows me to cross compare the effect of the level of salience on contentious issues.

The ICOW data set collected several measures of salience for each territorial claim. This was done by gathering characteristics of claimed territory such as its population, strategic terrain positioning, and the presence of valuable resources (tangible) and the presence of a country's ethnic or religious kinsmen, historical sovereignty over the territory, and homeland or colonial territory (intangible). Hensel (2001) combined these characteristics into a single measure of 
salience which can be used for intangible and tangible salience separately. The ICOW data set includes three indicating measures for each tangible and intangible salience.

Territory is considered to be more tangibly salient if it potentially possesses valuable natural resources such as oil, iron, or fisheries. Subsequently, territory is regarded as tangibly salient when it has an economic or militarily strategic location which provides security, trade routes, or a route to warm water port. Lastly, territory is considered more tangibly salient when it is able to uphold a consistent population, as measured by presence of permanent towns or villages.

The three measures ICOW salience uses for territory are considered to be more intangibly salient if the state considers the terrain to be part of its historical and national homeland, and if the state has ethnic, linguistic, or religious identity ties to it. The last measure used for intangible salience for territory is when a state declares sovereignty over a territory over which it has declared sovereignty in the past. These factors come together to create the ICOW salience measure. From there I derived both my high tangible and intangible variable from the ICOW salience measure. This variable is more specific to the cases where high levels of both tangible and intangible salience exist. However, due to great similarities and the fact that one variable derives from another, there was too much correlation between them and I could not run them.

\section{Dependent Variables}

Militarized interstate dispute beginning within a year (MIDISSYR). In order to determine the impact the level of salience has on armed conflict, levels of militarized interstate dispute were taken into account. According to Singer, Bremer and Jones (1996), for an event to be classified as a MID it must be a dispute between system member states that became militarized, involve multiple interstate members, and be a government authorized action. This 
variable represents the number of times a militarized interstate dispute occurred between two actors within a given year.

Fatal militarized interstate dispute beginning within a year (MIDIFATYR). This variable determines how many fatal militarized disputes occurred within a year. According to Singer, Bremer and Jones (1996) a fatal militarized dispute is considered to be an event which totals more than 1,000 deaths. Therefore, this variable represents how many times a militarized event causing more than 1,000 deaths occurred between states.

Role of organized violence in end of claim (ENDVIOL). In order to characterize the type of settlement that occurred between two states, the variable Endviol from the ICOW data set will be used. Endviol is characterized as 1, which is labeled violence and represents whether this claim ended due to large-scale organized violence between the claimant states, and 0 , which is labeled none and represents whether the claim did not end in violent means. Also, -9 is a claim coded that has passed the current end of the data set. Additionally, this variable does not represent cases where the violence was not organized or conducted by non-official forces (Hensel 2005).

Claim ended through peaceful techniques (ENDPEACE). This variable was created using the ICOW data set. Endpeace is characterized as either 1, which represents if the claim was resolved or ended through a peaceful third party or bilateral agreement, and 0 , which represents if the claim has not ended yet. This variable represents cases where peaceful measures are taken to end the conflict.

\section{Control Variables}

Challenger and target state share border (TCCONTBOTH). In order to gather information on the state's land border in relation to the territory, a contiguity variable was used. 
This variable is derived from the ICOW data set and is a combination of the challenger and target state that share a land border with the territory in question. The challenger and the target state do not necessarily share borders but it does share a land border with the territory being disputed.

Democracy scale (DEMAUT6). In order to account for whether the states involved are democratic or not, the Demaut6 variable was used. This variable characterizes if a state is a democratic by rating it on a scale from 1 to 10,1 being least democratic to 10 being most. A state receiving a 6 or above on the democratic-autocratic scale is considered democratic.

Relative capabilities (RELCAPS). In order to account for the relative capabilities of a state, this variable was used. This variable defines the relative capabilities of the stronger side in the claim (whether is it the challenger or the target state).

\section{Analysis and Discussion}

Table 2 represents the descriptive statics of the salience level's effects on armed conflicts for hypothesis one. As previously stated, hypothesis one claims that contentious issues with both high levels of tangible and intangible salience are more likely to produce armed conflicts than issues with low levels on one or both salience dimensions, particularly for more severe forms of conflict. As Table 1 shows, of the 6,052 cases accounted for, 240 resulted in a form of militarized dispute, 195 of them were just a militarized dispute that occurred within a year, and 45 of the cases were for fatal militarized disputes that occurred within a year. The distribution of the cases among the level of salience coincides with hypothesis one predictions. The other level of saliences result in significantly fewer cases, showing that the level of tangible and intangible salience have an effect on the outcome of armed conflicts. 
Table 3 represents the logit model ran for hypothesis one. In order to test this hypothesis specifically, an interaction term for the both high levels of tangible and intangible salience was created. I had to run the ICOW Salience variable and the interaction term separately because there is too much correlation between them and they would cancel one another out. Both the interaction term and ICOW Salience variable with the presence of a militarized dispute occurring within a year showed to be statistically significant. In Table 4 two models were constructed, which accounted for the interaction term and the ICOW Salience with the presence of fatal militarized disputes within a year. Here, too, the results show to be statistically significant. The results from both tables show support of my theory and hypothesis that the levels of salience have an effect on the outcome of the armed conflicts. Additionally, relative capability and contiguity increases the likelihood of fatal militarized and militarized disputes, while joint democracy makes no systematic difference. Consistent with democratic peace theory, though, no democracies have gone to war over territory.

Table 5 represents the descriptive analyses for the salience level's effects on peaceful settlements for hypothesis two. Here, too, it is suggested that when a contentious issue has high levels of both tangible and intangible salience, it is more likely to produce peaceful agreements by making the issue more important to the actors to resolve. Table 4 shows that out of the 171 cases accounted for, 61 ended in peaceful (42 cases) or violent means (19 cases). The distribution of the level of salience does support the hypothesis that high levels of both tangible and intangible salience are more significant; the logit models with the interaction term reveal different results.

In Table 6 and Table 7, logit models were run for hypothesis two. The same interaction term and the ICOW Salience variable were run separately due to their strong correlation. Table 5 
and Table 6 show that the ICOW Salience variable is statistically significant for claims ending in peaceful arrangements. Additionally, the role of territorial contiguity and relative capabilities increase the likelihood of a claim ending in peaceful arrangements. However, this is not the same for the interaction term. In both of the tables it shows not to be statistically significant. This does not support the theory that the levels of high tangible and intangible salience will increase the importance of the issue, making it more important to find a resolution. It shows the contrary that since there are high levels of both saliences, it is more difficult to resolve for a country.

\section{Conclusion}

This study sought to determine whether the high levels of both tangible and intangible salience produce more armed conflicts or peaceful agreements than other levels of salience. Answering this question has important implications for the study of territory and the role of salience. In relation to territory, this study shows that the dimensions and factors that make up territory play a significant role in the outcome of contentious issues dealing with territory. Overall, it further expands the literature on why and how territory is contentious. In terms of the study of salience level, my research shows that high levels of both tangible and intangible salience are much more significant in producing armed conflicts than other levels. Even though it was hypothesized that these high levels would also produce more peaceful agreements, this study shows that it is not the case. This further explains the role levels of salience have upon one another showing that the level of salience helps determine the outcome of the contentious issue. Moreover, this study seeks to explain the relationship of salience levels and the outcomes of contentious issues. In order to explain this relationship and outcomes of territorial issues, several logistic and descriptive analysis models were composed, incorporating the presence of both high 
tangible and intangible salience with armed conflicts and peaceful agreements and see if there was any significant interaction between these factors.

Ultimately, it was found that high level of tangible and intangible salience had no significant influence on whether a situation would end in a peaceful settlement. However, this result provides valuable findings by showing that contentious issues with such high levels of salience cause the situation to become more difficult to resolve. This outcome differs from previous research, which shows that high levels of intangible salience increase the likelihood of producing peaceful agreements (Hensel \& Mitchell 2005). This research shows that when both high levels of tangible and intangible salience are present, tangible salience cancels out the likelihood that the situation will end in a peaceful agreement. However, the significant influence that high levels of salience have upon armed conflicts shows that the interaction between these two factors does increase the likelihood of producing armed conflicts. This further expands upon what was known about level of salience and that the levels of salience do affect the outcome of the contentious issue.

Overall these results were somewhat consistent with the theory and hypothesis. Even though there was no significant relationship between high levels of salience and peaceful agreements, my research did show another dimension of the relationship between salience and peaceful agreements. Previous works have explained the role of these two types of salience individually upon a contentious issue and territory but had not explored them together. This research shows that the presence of these factors together in a issue does have an interactive effect with one another through the results of different levels of salience has upon armed conflict and peaceful agreements. 


\section{Bibliography}

Diehl, P.F. (1992). "What are they fighting for? The importance of issues in international conflict research.” Journal of Peace Research 29:333-334.

Fearon J.D. (1995). “Rationalist explanations for war.” International Organization 49:379-414.

Hensel P.R., Mitchell S., Sowers T.E., and Thyne C.L. (2008). "Bones of Contention: Comparing Territorial, Maritime, and River Issues." Journal of Conflict Resolutions 52:117-143.

Hensel P.R. (1999). “An Evolutionary Approach to the Study of Interstate Rivalry.” Conflict Management and Peace Science 17, 2 (Fall):179-206.

Hensel P.R. (1996). "Charting a course to conflict: territorial issues and militarized interstate disputes, 1816-1992.” Conflict Management and Peace Science 15:43-73.

Hensel P.R. (2001). "Contentious issues and world politics: territorial claims in the Americas, 1816-1992.” International Studies Quarterly 45:81-109.

Hensel P.R. (2000). “Territory: theory and evidence on geography and conflict.” In Vasquez, J.A (ed.), What Do We Know about War? Rowman and Littlefield: Maryland.

Hensel P.R. and Mitchell, S. (2005). "Issue Indivisibility and Territorial Claims." GeoJournal 64:275-85.

Huth P.K. and Allee T. (2002). The Democratic Peace and Territorial Conflict in the Twentieth Century. New York: Cambridge University Press.

Huth P.K., (1996). Standing Your Ground: Territorial Disputes and International Conflict. University of Michigan Press: Ann Arbor.

Jones D., Bremer S. and Singer J. (1996). “Militarized Interstate Disputes, 1816-1992: Rationale, Coding Rules and Empirical Patterns." Conflict Management and Peace Science.

Laurd E. (1970). The International Regulation of Frontier Disputes. Praeger: New York.

Mansbach R. and Vasquez J. (1981). In Search of Theory: A New Paradigm for Global Politics. Columbia University Press: New York.

Mitchell, S. M. and Prins, B.C. (1999). "Beyond territorial contiguity: issues at stake in democratic militarized interstate dispute.” International Studies Quarterly 43:169-183.

Senese P.D. and Vasquez J.A. (2003). "A unified explanation of territorial conflict: testing the impact of sampling bias, 1919-1992.” International Studies Quarterly 47:275-298. 
Senese P.D. (1996). "Geographical proximity and issue salience: their effect on the escalation of militarized interstate conflict." Conflict Management and Peace Science 15:133-161.

Vasquez J.A. and Henehan M.T. (2001). "Territorial disputes and the probability of war, 18161992." Journal of Peace Research 38:123-138. 
Table 1: Combinations of Levels of Tangible and Intangible Salience

\section{Combinations of Levels of Tangible and Intangible Salience}

High Intangible \& Low Tangible Salience

These issues focus more on impalpable factors than economic factors. The probable outcome is that it would produce more armed conflicts and peaceful agreements, due to the symbolic connection the actors involved have to the situation.

High Intangible \& High Tangible Salience

These issues focus both on indefinable and concrete factors. The probable outcome is more armed conflicts or peaceful agreements because the high focus on both of these factors increases the importance of the issue, making more conflicts and settlements likely.

\section{High Tangible \& Low Intangible Salience}

These issues focus more on the concrete factors than symbolic dimensions. The probable outcome is that it would produce less armed conflict and less peaceful agreements to occur because tangible factors are easier to negotiate and compromises are easier to reach, since they are divisible factors.

\section{Low Intangible \& Low Tangible Salience}

The probable outcome is neither a high chance of armed conflict or peaceful agreement, due to its lack of ability to incite conflict. 
Table 2: Descriptive Analysis of Salience Measures Effects on Armed Conflicts Within a Year

\begin{tabular}{|l|c|c|c|c|c|}
\hline $\begin{array}{l}\text { Militarized } \\
\text { Dispute within } \\
\text { a year }\end{array}$ & $\begin{array}{c}0 \\
\text { Level of Salience } \\
\text { 0=lo tan- lo in }\end{array}$ & $\begin{array}{c}\text { Level of Salience } \\
\text { 1=lo tan- high in }\end{array}$ & $\begin{array}{c}2 \\
\text { Level of Salience } \\
\text { 2=high tan- low in }\end{array}$ & $\begin{array}{c}\text { Level of Salience } \\
\text { 3=high tan- high in }\end{array}$ & Total \\
\hline 0 (No) & 1,334 & 1,758 & 721 & 2,044 & 5,857 \\
& 99.26 & 98.65 & 95.50 & 94.15 & 96.78 \\
\hline 1 (Yes) & 10 & 24 & 34 & 127 & 195 \\
& 0.74 & 1.35 & 4.50 & 5.85 & 3.22 \\
\hline \multicolumn{1}{|c|}{ Total } & 1,344 & 1,782 & 755 & 2,171 & 6,052 \\
& 100.00 & 100.00 & 100.00 & 100.00 & 100.00 \\
\hline
\end{tabular}

\begin{tabular}{|c|c|c|c|c|c|}
\hline $\begin{array}{l}\text { Fatal } \\
\text { Militarized } \\
\text { Dispute within } \\
\text { a year }\end{array}$ & \begin{tabular}{l}
\multicolumn{1}{c}{0} \\
Level of Salience \\
$0=$ lo tan- lo in
\end{tabular} & $\begin{array}{l}1 \\
\text { Level of Salience } \\
1=\text { lo tan- high in }\end{array}$ & $\begin{array}{l}2 \\
\text { Level of Salience } \\
2=\text { high tan- low in }\end{array}$ & $\begin{array}{l}\text { 3 } \\
\text { Level of Salience } \\
\text { 3=high tan- high in }\end{array}$ & Total \\
\hline $0(\mathrm{No})$ & $\begin{array}{l}1,343 \\
99.93\end{array}$ & $\begin{array}{l}1,776 \\
99.66\end{array}$ & $\begin{array}{c}753 \\
99.74\end{array}$ & $\begin{array}{l}2,135 \\
98.34\end{array}$ & $\begin{array}{l}6,007 \\
99.26\end{array}$ \\
\hline 1 (Yes) & $\begin{array}{c}1 \\
0.07\end{array}$ & $\begin{array}{c}6 \\
0.34\end{array}$ & $\begin{array}{c}2 \\
0.26\end{array}$ & $\begin{array}{c}36 \\
1.66\end{array}$ & $\begin{array}{c}45 \\
0.74\end{array}$ \\
\hline Total & $\begin{array}{c}1,344 \\
100.00\end{array}$ & $\begin{array}{c}1,782 \\
100.00\end{array}$ & $\begin{array}{c}755 \\
100.00\end{array}$ & $\begin{array}{c}2,171 \\
100.00\end{array}$ & $\begin{array}{c}6,052 \\
100.00\end{array}$ \\
\hline
\end{tabular}


Table 3: Coefficient Estimates of Militarized Disputes Within a Year

3A: Baseline Model

\begin{tabular}{|l|c|}
\hline \multicolumn{1}{|c|}{ Independent \& Control Variables } & Militarized Dispute within a Year \\
\hline ICOW Salience & $.22^{* * *}$ \\
& $(.037)$ \\
\hline Territory Contiguity & -.04 \\
& $(.107)$ \\
\hline Level of Democracy & $-.60 * *$ \\
& $(.28)$ \\
\hline Relative Capabilities & $-2.6^{* * *}$ \\
& $(.517)$ \\
\hline Constant & $-2.7 * * *$ \\
& $(.539)$ \\
\hline Pseudo R2 & 0.066 \\
\hline
\end{tabular}

3B: Tangible and Intangible Salience Effects on Militarized Disputes within a Year

\begin{tabular}{|l|c|}
\hline \multicolumn{1}{|c|}{ Independent \& Control Variables } & Militarized Dispute within a Year \\
\hline High Tangible \& Intangible Salience & $1.47 * *$ \\
& $(.355)$ \\
\hline High Tangible \& Low Intangible Salience & $1.64 * * *$ \\
& $(.365)$ \\
\hline Low Tangible Salience \& High Intangible & .07 \\
& $(.404)$ \\
\hline Territory Contiguity & $.247^{*}$ \\
& $(.120)$ \\
\hline Level of Democracy & -.46 \\
& $(.280)$ \\
\hline Relative Capabilities & $-2.76^{* * *}$ \\
& $(.507)$ \\
\hline Constant & $-2.5 * * *$ \\
& $(.552)$ \\
\hline Pseudo R2 & 0.085 \\
\hline
\end{tabular}

$* \mathrm{P}<.05, * * \mathrm{p}<.01, * * * \mathrm{p}<.001$ 
Table 4: Coefficient Estimates of Fatal Militarized Dispute within a Year

\section{A: Baseline Model}

\begin{tabular}{|l|c|}
\hline \multicolumn{1}{|c|}{ Independent \& Control Variables } & Fatal Militarized Dispute within a Year \\
\hline ICOW Salience & $.30 * * *$ \\
& $(.076)$ \\
\hline Territory Contiguity & .41 \\
& $(.27)$ \\
\hline Level of Democracy & -.94 \\
& $(.73)$ \\
\hline Relative Capabilities & -1.9 \\
& $(1.09)$ \\
\hline Constant & $-5.97 * * *$ \\
& $(1.20)$ \\
\hline Pseudo R2 & 0.094 \\
\hline
\end{tabular}

4B: Tangible and Intangible Salience Effects on Fatal Militarized Disputes within a Year

\begin{tabular}{|l|c|}
\hline \multicolumn{1}{|c|}{ Independent \& Control Variables } & Fatal Militarized Dispute within a Year \\
\hline High Tangible \& Intangible Salience & $2.2^{*}$ \\
& $(1.05)$ \\
\hline High Tangible \& Low Intangible & 1.17 \\
Salience & $(1.23)$ \\
\hline Low Tangible Salience \& High & .85 \\
Intangible & $(1.11)$ \\
\hline Territory Contiguity & .52 \\
& $(.289)$ \\
\hline Level of Democracy & -.80 \\
& $(.73)$ \\
\hline Relative Capabilities & $-2.34 *$ \\
& $(1.06)$ \\
\hline Constant & $-5.38^{* * *}$ \\
& $(1.40)$ \\
\hline Pseudo R2 & 0.10 \\
\hline
\end{tabular}

$* \mathrm{P}<.05, * * \mathrm{p}<.01, * * * \mathrm{p}<.001$ 
Table 5: Descriptive Analyses of Salience Measures Effects on Peaceful Settlement

\begin{tabular}{|l|c|c|c|c|c|}
\hline $\begin{array}{l}\text { Did a Claim } \\
\text { End Peacefully? }\end{array}$ & $\begin{array}{c}0 \\
\text { Level of Salience } \\
\text { 0=lo tan- lo in }\end{array}$ & $\begin{array}{c}\text { Level of Salience } \\
\text { 1=lo tan- high in }\end{array}$ & $\begin{array}{c}2 \\
\text { Level of Salience } \\
\text { 2=high tan- low in }\end{array}$ & $\begin{array}{c}\text { Level of Salience } \\
\text { 3=high tan- high in }\end{array}$ & Total \\
\hline 0 (No) & 17 & 7 & 10 & 31 & 65 \\
& 44.74 & 18.42 & 45.45 & 42.47 & 38.01 \\
\hline 1 (Yes) & 21 & 31 & 12 & 42 & 106 \\
& 55.26 & 81.58 & 54.55 & 57.53 & 61.99 \\
\hline \multicolumn{1}{c|}{ Total } & 38 & 38 & 22 & 73 & 171 \\
& 100.00 & 100.00 & 100.00 & 100.00 & 100.00 \\
\hline
\end{tabular}

\begin{tabular}{|l|c|c|c|c|c|}
\hline $\begin{array}{l}\text { Did Claim end } \\
\text { through } \\
\text { Violence? }\end{array}$ & $\begin{array}{c}0 \\
\text { Level of Salience } \\
\text { 0=lo tan- lo in }\end{array}$ & $\begin{array}{c}\text { Level of Salience } \\
\text { 1=lo tan- high in }\end{array}$ & $\begin{array}{c}2 \\
\text { Level of Salience } \\
\text { 2=high tan- low in }\end{array}$ & $\begin{array}{c}3 \\
\text { Level of Salience } \\
\text { 3=high tan- high in }\end{array}$ & Total \\
\hline 0 (No) & 38 & 36 & 21 & 54 & 149 \\
& 100.00 & 94.74 & 95.45 & 73.97 & 87.13 \\
\hline 1 (Yes) & 0 & 2 & 1 & 19 & 22 \\
& 0.00 & 5.26 & 4.55 & 26.03 & 12.87 \\
\hline Total & 38 & 38 & 22 & 73 & 171 \\
& 100.00 & 100.00 & 100.00 & 100.00 & 100.00 \\
\hline
\end{tabular}


Table 6: Coefficient Estimates, Whether Claim Ended through Peaceful Arrangements

6A: Baseline Model

\begin{tabular}{|l|c|}
\hline \multicolumn{1}{|c|}{ Independent \& Control Variables } & Claims Ending in Peaceful Arrangements \\
\hline ICOW Salience & $-.20 *$ \\
& $(0.07)$ \\
\hline Territory Contiguity & $.48^{*}$ \\
& $(.23)$ \\
\hline Democracy Level & .20 \\
& $(.47)$ \\
\hline Relative Capabilities & $-3.06^{*}$ \\
& $(1.23)$ \\
\hline Constant & $3.19^{* * *}$ \\
& $(1.29)$ \\
\hline Pseudo R2 & 0.072 \\
\hline
\end{tabular}

6B: Model of Levels of Tangible and Intangible Salience Effects on Peaceful Arrangements

\begin{tabular}{|l|c|}
\hline \multicolumn{1}{|c|}{ Independent \& Control Variables } & Claims Ending in Peaceful Arrangements \\
\hline High Tangible \& Intangible Salience & -.28 \\
& $(.497)$ \\
\hline High Tangible \& Low Intangible Salience & -.106 \\
& $(.569)$ \\
\hline Low Tangible Salience \& High Intangible & $1.13^{*}$ \\
& $(.610)$ \\
\hline Territory Contiguity & .14 \\
& $(.241)$ \\
\hline Democracy Level & .094 \\
& $(.476)$ \\
\hline Relative Capabilities & $-2.91^{* *}$ \\
& $(1.21)$ \\
\hline Constant & $2.76^{* *}$ \\
& $(1.18)$ \\
\hline Pseudo R2 & 0.076 \\
\hline
\end{tabular}

$* \mathrm{P}<.05, * * \mathrm{p}<.01, * * * \mathrm{p}<.001$ 
Table 7: Coefficient Estimates, Whether Claim Ended through Violence

7A: Baseline Model

\begin{tabular}{|l|c|}
\hline \multicolumn{1}{|c|}{ Independent \& Control Variables } & Claims Ending Through Violence \\
\hline ICOW Salience & $.42^{* * *}$ \\
& $(.134)$ \\
\hline Territory Contiguity & .99 \\
& $(.540)$ \\
\hline Democracy Level & $-.545^{*}$ \\
& $(.783)$ \\
\hline Relative Capabilities & -.16 \\
& $(1.75)$ \\
\hline Constant & $-6.64 * * *$ \\
& $(2.17)$ \\
\hline Pseudo R2 & 0.239 \\
\hline
\end{tabular}

7B: Levels of Tangible and Intangible Salience Effects on Violent Methods

\begin{tabular}{|l|c|}
\hline \multicolumn{1}{|c|}{ Independent \& Control Variables } & Claims Ending through Violence \\
\hline High Tangible \& Intangible Salience & 17.1 \\
& $(3823.8)$ \\
\hline High Tangible \& Low Intangible & 16.7 \\
Salience & $(3823.8)$ \\
\hline Low Tangible Salience \& High & 15.4 \\
Intangible & $(3823.8)$ \\
\hline Territory Contiguity & 1.3 \\
& $(.679)$ \\
\hline Democracy Level & -.076 \\
& $(.74)$ \\
\hline Relative Capabilities & -.545 \\
& $(1.68)$ \\
\hline Constant & -20.1 \\
& $(3823.8)$ \\
\hline Pseudo R2 & 0.250 \\
\hline
\end{tabular}

$* \mathrm{P}<.05, * * \mathrm{p}<.01, * * * \mathrm{p}<.001$ 